\title{
Lisede Okul Tükenmişliğinin Akademik Bağlamda Ödül Bağımlılığı ile Yordanması
}

\section{Predicting School Burnout Based on Reward Addiction in Academic Contexts in High School}

\begin{abstract}
Ayşe AYPAY*
Öz. Akademik bağlamda ödül bağımlılığının haz duygusunu deneyimlemede dışarıya bağımlılık haline neden olabilmesi ve ödülsüzlük ipuçlarının öğrencilerde strese, olumsuz duygu ve davranışlara yol açabilmesi durumlarının, okulda uzun dönem stres faktörlerinin yol açtığı okul tükenmişliği ile ilişkili olabileceği öngörülmektedir. Bu nedenle, bu çalışmada lise öğrencilerinin ödül bağımlılı̆̆ının yaşadıkları okul tükenmişlik sendromunun anlamlı bir yordayıcısı olup olmadığının belirlenmesi amaçlanmıştır. Örneklem grubu Eskişehir'de yer alan iki devlet lisesinde öğrenimini sürdüren; 9, 10 ve 11. sınıfa devam eden toplam 265 öğrenciden oluşmaktadır. Veriler Lise Öğrencileri için Ödül Bağımlılı̆̆ Ölçeği ve Ortaöğretim Öğrencileri için Okul Tükenmişliği Ölçeği kullanılarak toplanmıştır. Veriler Çoklu Doğrusal Regresyon Analizleri ile analiz edilmiştir. Analiz sonuçları akademik bağlamda ödül bağımlıı̆ının lise öğrencilerinin okul tükenmişliğini düşük düzeyde yordadığını göstermiştir. Akademik bağlamda ödül bağımlılı̆̆ aileden kaynaklı tükenmişlik ve öğretmen tutumlarından bunalma ve sıkılma tükenmişlik boyutlarındaki toplam varyansları diğer tükenmişlik boyutlarına göre daha büyük bir oranda açıklamaktadır. Bu çalışmanın bulgularının okul tükenmişliğinin düşük düzeyde de olsa yordayıcısı olan bir değişkeni literatüre tanıttığı için önemli olduğu düşünülmektedir.
\end{abstract}

Anahtar Kelimeler: Okul tükenmişliği, ödül bağımlılı̆̆ı, akademik bağlam, lise, öğrenci.

Abstract. It is hypothesised that reward addiction in the academic context causing dependence to the outside world in experiencing the feeling of pleasure and noreward clues leading to stress as well as negative feelings and behaviours in students can be related to school burnout that is caused by long-term stress factors at school. For this reason, this study aimed to determine whether high school students' reward addiction was a significant predictor of the school burnout syndrome they experienced. The participants were 265 students who were studying at 9th, 10th and 11 th grades at two state high schools in Eskişehir. Reward Addiction Scale for High School Students, and School Burnout Scale For High School Students were employed to gather the data. Multiple Linear Regression Analysis was conducted to analyse the data gathered. The analyses revealed that reward addiction in the academic context predicted high school students' school burnout at a weak level. Reward addiction in the academic context explained the variances in burnout due to family and being bored and tired of teacher attitudes to a higher extent compared to other burnout dimensions. It is thought that the findings of this study are of significance since it introduces a variable that is a predictor, although at a weak level, of school burnout to the literature.

Keywords: School burnout, reward addiction, academic context, high school, student.

Toplumsal Mesaj. Bu
çalışmada akademik
bağlamda ödül bağımlılığının
lise öğrencilerinde okul
tükenmişliğini yordayıcı bir
değişken olup olmadığı
belirlenmeye çalışılmıştır.
Öğrencilerin akademik görev
ve sorumluluklarını dışsal bir
faktör olan ödül koşuluna
bağlı olarak yerine getirme
alışkanlığı geliştirmeleri
onları öngöremedikleri bir
psikolojik sorun olan
tükenme sendromuna
taşıyabilir.

Public Interest Statement. This study aimed to determine whether reward addiction in the academic context is a variable that can predict school burnout in high school students. Students' developing the habit of fulfilling their duties and responsibilities depending on the reward condition as an external factor may cause burnout syndrome, a psychological problem that they cannot foresee.

\footnotetext{
* Doç. Dr., Eskişehir Osmangazi Üniversitesi Eğitim Fakültesi, Eğitim Bilimleri Bölümü, ayseaypay@hotmail.com 


\section{GíRiş}

Akademik bağlamın en önemli ögesi olan ve eğitim-öğretim faaliyetleri ile öğrencilerin iyi bir gelecek inşa etmelerine hizmet eden okulların aynı zamanda öğrencilerin tükenme sendromu yaşamalarının bir nedeni olmasında şüphesiz okullarda maruz kalınan yaşantıların rolü vardır. Bu yaşantılardan biri ödüllendirmedir. Okullarda eğitim öğretim faaliyetleri gerçekleştirilirken, bu faaliyetlerin amacına ulaşmasında ve etkili olmasında hizmet edecek bir araç olarak eğitim sistemlerinin kaçınılmaz bir parçası haline gelen ödüllendirmelere sıkça yer verilmektedir. Gerçekte ödül, yapılması istenen ve onaylanan bir davranışın bireyler tarafından daha sık gösterilmesini sağlamak için yapılan davranışın ardından kişiye sunulan hoşa giden bir uyarıcıdır (Reynolds, 1975). Thorndike (Roeckelein, 1998) ve Skinner (Reynolds, 1975; Skinner, 1971) gibi bazı davranışçı psikologlara göre ödüllendirme bireylerin doğru davranma potansiyellerini artırıcı bir işleve sahiptir. Tolman (Ormrod, 2011; Tolman ve Honzik, 1930; Tolman, 1938) ve Bandura (1976) ise ödüllerin bireylerin öğrendiklerini davranışsal olarak sergilemelerinde yani performanslarını geliştirmelerinde güdüsel bir araç olduğunu ileri sürmüşlerdir. Daha sonraki yıllarda da dişsal ödüllendirmelerin davranışa güdüsel müdahale stratejisi ve davranışı kontrol eden bir teknik olarak değerine işaret edilmiştir. (Cameron ve Pierce, 1994; Ching, 2012; Covington, 2000; Deci ve diğerleri, 1999; Pintrich, 2000).

Ödülendirmeye dair bu olumlu bakış açılarına karşın, literatürde azımsanmayacak sayıdaki çalışmada ödüllendirmenin öğrencilerin psikolojileri üzerinde ortaya çıkardığı olumsuz etkilerden söz etmektedir. Sayısı yüzü aşan bilimsel araştırma üzerinde yapılan bir meta-analiz çalışması (Deci ve diğerleri, 1999) dışsal ödüllerin genel olarak içsel motivasyonu azalttığını ortaya koymuştur. Bu durumun ödüllendirilen bireylerin yaşları, yapılan etkinliklerin türü ve ödüllendirme çeşitlerinde ortak bir etki olduğu tespit edilmiştir.

Bazı çalışmalar farklı ödül tiplerinin farklı yaş gruplarında farklı etkiler ortaya çıkarabildiğini göstermektedir. Örneğin Levitt, List, Necerkmann ve Sadoff'un (2012) çalışması mali olmayan ödüllerin ilkokul çocuklarının performanslarını artırdı̆̆ını, ancak lise öğrencilerinde bu etkiye sahip olmadığını göstermiştir. Aynı çalışmada lise öğrencilerinde mali ödüllerin ancak performansın hemen arkasından verilirse (gelecekte değil) etkili olduğu da belirlenmiştir.

Ödüllerin öğrencilerde toplumsal müeyyideye uğrama korkusuna yol açabildiği de belirlenmiştir. Örneğin Bursztyn ve Jensen (2014) lise öğrencileri üzerinde yaptıkları bir deneysel çalışmada, en iyi performansların tüm öğrencilerin görebileceği bir puan tablosunda sergilenmesi biçimindeki ödüllendirmenin öğrencilerin performanslarındaki etkilerine bakmışlardır. Araştırmanın bulguları böyle bir ödüllendirmeye geçişin öğrencilerin performansında genel olarak \%13'lük bir düşüşe neden olduğunu, en yüksek puan alan öğrencilerin perpormanstaki düşüş açısından en yüksek risk grubunu oluşturduğunu, bu öğrencilerde performans düşüşünün \%24 olduğunu ancak en düşük performanstaki öğrenciler açısından bu ödüllendirme biçiminin küçük düzeyde bir iyileşmeye yol açtığını göstermiştir. Araştırmacılar bu tip ödüllendirmelerin öğrencilerde akranları tarafından toplumsal müeyyideye maruz kalma korkusuna yol açtığını ve bu korku nedeniyle performans düşüşü yaşandığını düşünmektedirler. Aynı araştırmacılar ödüllerin olduğu çevrelerin kişilerde baskı oluşturabileceği ve işbirliği yerine yarışmacı zihniyetleri destekleyeceğini ileri sürmektedir.

Ödülendirmenin etkilerine dair bazı araştırma (Delgado, Locke, Stenger ve Fiez, 2003; Knutson, Adams, Fong ve Hommer, 2001) bulguları, bir işin ardından ödül verileceği bilgisine sahip bireylerde ödüllere karşı bağımlılık geliştiğini göstermiştir. Bir başka ifade ile beyin bağımlıık yapıcı uyarıcı durumlara verdiği tepkilere çok benzeyen tepkileri ödül uyarııılarına karşı da vermektedir. Her iki durumda da bireyler kısa süreli bir rahatlama yaşayıp ardından yeni bir doz isteği içine girmektedirler (Pink, 2009).

Akademik bağlamda ödül bağımlılığı konusu Aypay'ın (2015; 20016a ve b) çalışmalarında ele alınmıştır. Akademik bağlamda ödül bağımlılığı, bir öğrencinin akademik bağlamda duygu durumunun ve davranışının ödüller tarafından kontrol edilmeye başlanması hali olarak tanımlanmaktadır (Aypay, 2016b). Aypay (2015), ödüllendirme uygulamalarının davranışa dışsal 
müdahaleler olması nedeniyle, bireyin kontrol algısını zayıflatacağını ve ödüle bağımlı hale gelen bir bireyin ödül alamama işaretleri karşısında strese gireceği ve negatif duygu ve davranışlar üretebileceği öngörüsünde bulunmaktadır. Bu öngörüyü destekleyen bir bulgu lise öğrencileri üzerinde yapılan çalışmadan elde edilmiştir. Bu çalışmanın bulgularına göre, lise öğrencilerinde ödül bağımlılığı, ceza hassasiyetini anlamlı ve pozitif yönde etkilemektedir.

Akademik bağlamda ödül bağımlılı̆ının haz duygusunu deneyimlemede dışarıya bağımlılık haline neden olması ve ödülsüzlük ipuçlarının öğrencilerde strese ve olumsuz duygu ve davranışlara yol açabilmesi durumu, okulda uzun dönem stres faktörlerinin yol açtığı okul tükenmişliğini (Aypay, 2011) akla getirmektedir. Okul tükenmişliği sendromunun öğrencilerin akademik yaşamlarını olumsuz yönde ve ciddi bir biçimde etkilediği araştırma bulgularında ortaya konulmuştur. Örneğin okul tükenmişliği öğrencilerin akademik öz-yeterliklerinde azalmaya (Duru, Duru ve Balkıs, 2014), okulu bırakmalarına (Bask ve Salmela-Aro, 2013; Dyrbye, Thomas, Power, Durning, Moutier, Massie Jr. ve diğerleri, 2010), intihar düşüncesi geliştirmelerine (Dyrbye, Thomas, Harper, Massie Jr, Power, Eacker ve diğerleri, 2009) neden olabilmektedir. Okul tükenmişliği katılımla da olumsuz yönde korelasyon göstermektedir (Schaufeli, Martínez, Pinto, Salanova, ve Bakker, 2002). Bir başka ifade ile okul tükenmişlik düzeyleri yüksek öğrencilerin okula katılımlarının düzeyi daha düşük olmaktadır. Bu kadar ciddi olumsuz sonuçlara neden olabilen okul tükenmişliği konusunun farklı boyutları açısından ele alınması bu sendroma yol açabilen faktörlerin ve öğrencilerin okul tükenmişliği sendromu geliştirmelerinin önüne geçebilecek önleyici ve koruyucu tedbirlerin bilinmesi açısından önem taşımaktadır. Akademik bağlamda ödül bă̆ımlılığının öğrencilerde okul tükenmesine neden olabileceği düşünülmektedir. Literatürde akademik bağlamda ödül bağımlılı̆ının okul tükenmesiyle ilişkisini ele alan bir çalışmaya rastlanmamıştır. Bu nedenle bu çalışmada lise öğrencilerinin ödül bağımlıı̆ının yaşadıkları okul tükenmişlik sendromunun anlamlı bir yordayıcısı olup olmadığının belirlenmesi amaçlanmıştır. Bu çalışmanın bulgularının ödüllendirmeye sıkça başvuran ebeveynler, eğitimciler kadar öğrenciler açısından da ödül-tükenme ilişkisi konusunda bilinçlendirici olacağı düşünülmektedir. Öğrenim yaşantısının uzun bir sürece yayıldığı dikkate alındığında, bu uzun süreç boyunca öğrencilerin akademik pek çok görev ve sorumluluklarının olacağı açıktır. Öğrencilerin bu uzun süren öğrenim yaşantısından optimum düzeyde yarar sağlamalarında öğrenme çabalarının içten gelen bir öğrenme isteğine bağlı olmasının önemi şüphe götürmeyecek bir gerçek olarak kabul edilmektedir. Bunun aksine, öğrencilerin bu görev ve sorumluluklarını dışsal bir faktör olan ödül koşuluna bağlı olarak yerine getirme alışkanlığı geliştirmeleri onların öğrenme düzeyi ve kalitesini olumsuz etkileyeceği gibi onları öngöremedikleri bir psikolojik sorun olan tükenme sendromuna da taşıyabilir. Bu konuda bilinç kazanmış öğrencilerin akademik görev ve sorumluluklarını ödül alma koşulundan bağımsız olarak ve öğrenmeye daha yüksek bir değer atfederek yerine getirebilecekleri bu durumun da onlarda okul tükenme sendromu gelişmesi olasılı̆̆ını azaltabileceği düşünülmektedir.

\section{YÖNTEM}

Bu araştırma lise öğrencilerinde görülebilecek okul tükenmişlik sendromu ve akademik bağlamda ödül bağımlılı̆̆ arasındaki yordayıcı ilişkiyi belirlemeye dayalı olduğundan ilişkisel tarama modelinde bir çalışmadır.

\section{1. Örneklem}

Bu araştırmanın evrenini Eskişehir'deki liseler oluşturmaktadır. Seçkisiz örnekleme yöntemlerinden amaçlı örneklemenin tipik durum örneklemesi yöntemi ile seçilen Eskişehir merkezinde yer alan iki devlet lisesinde öğrenimini sürdüren; 9, 10 ve 11. sınıfa devam eden toplam 265 öğrenci bu araştırmanın örneklemini oluşturmaktadır. Öğrencilerden 12. sınıfa devam edenlerin bir kısmı üniversiteye giriş sınavlarına hazırlanmaları nedeniyle okula düzenli devam etmediğinden bir kısmı da aynı gerekçe ile araştırmaya zaman ayırmak istemediğinden bu araştırma örneklemine dâhil edilmemiştir. Öğrencilerin okullara dağılımı 120 (\%45.28), 145 (\%54.72) biçimindedir. Öğrencilerin 
165'i (\%62.3) kız, 100'ü (\%37.5) erkektir. Öğrencilerin 59'u (\%22.3) dokuzuncu sınıf; 144'ü (\%54.3) onuncu sınıf; 62'si (\%23.4) on birinci sınıf öğrencisidir.

\subsection{Veri Toplama Araçları}

Bu araştırmada öğrencilerin akademik bağlamda ödül bağımlılık düzeylerinin belirlenmesi amacıyla Lise Öğrencileri için Ödül Bağımlılı̆ı Ölçeği; öğrencilerin okul tükenmişlik düzeylerinin belirlenmesi amacıyla da Ortaöğretim Öğrencileri için Okul Tükenmişliği Ölçeği kullanıımıştır.

\subsubsection{Lise Öğrencileri için Ödül Bağımlılığı ölçeği (LööBö)}

Ölçek, Aypay (2015) tarafından geliştirilmiş olup yapı geçerliği AFA ve DFA analizleri ile test edilmiştir. AFA'da KMO değeri 0.95 olup; Bartlett's Testi sonucu $\left(\chi^{2^{(153)}}=5321,719, p<.001\right)$, manidar bulunmuştur. Varimax Döndürme sonrası, öz değeri 1'den büyük ve toplam varyansın \% 64'ünü açıklayan üç faktörlü bir yapı belirlenmiştir. Faktörlerin isimleri, özdeğerleri ve açıkladıkları varyanslar sırasıyla şöyledir: Ödül Beklentisine Bağı Şartlı Performans (5.83; \% 32.42), Ödülün Okulda Pekiştirme Etkisi (3.17; \% 17.62), Ödülün Evde Pekiştirme Etkisi (2.55; \% 14.18). Üç faktörün maddelerle ilgili ortak varyansları .44 ile .77 arasındadır. LÖÖBÖ’nün faktörleri toplam puanla yüksek, birbirleriyle orta düzeyde bir korelasyona sahiptir. LÖÖBÖ'nün AFA ile belirlenen yapısını doğrulamak için uygulanan birinci Düzey DFA'da ölçeğin 2. ve 3. boyutları yüksek düzeyde korelasyon gösterdiğinden ölçeğe ikinci düzey DFA uygulanmıştır. Modelin uyum indeksleri $\left[\chi^{2^{(122)}}\right.$ $\left.=220,786, \quad \mathrm{p}<.01, \chi^{2} / \mathrm{sd}=1,810, \mathrm{GFI}=.916, \quad \mathrm{FI}=.962, \quad \mathrm{CFI}=.962, \mathrm{RMSEA}=.057\right]$ modelin büyük oranda iyi uyum gösterdiğini ortaya koymuştur. LÖÖBÖ faktörleri için Cronbach Alpha güvenirlik katsayıları sırasıyla şöyledir: .93, .92, .86. Ölçekteki tüm maddelerin madde-toplam korelasyonları .43 - .75 arasındadır. Ölçekten alınan yüksek puanlar yüksek ödül bağımlıı̆ına işaret etmektedir. Ödül Beklentisine Bağıı şartlı Performans boyutu, ödülün kişide oluşturduğu bağımlılık halini anlatmaktadır. Bu boyuttaki madde örnekleri şöyledir: "Ders çalışmaya başlamadan önce, anne ve babamla karşıı̆ı̆ında bana ödül olarak ne vereceklerinin pazarlığını yaparım." ve "Okuldaki her başarımdan sonra, annem ve babamın daha önce verdiği ödüllerden daha büyüğünü almayı beklerim." Ödülün Okulda Pekiştirme Etkisi boyutu, okuldaki ödül uygulamalarına karşı gelişmiş yüksek hassasiyet durumunu anlatmaktadır. Bu boyuttaki madde örnekleri şöyledir: "Bir derste ödüllendirilirsem o derse olan ilgim artar." ve "Okul daha çok ödül verilen bir yer olsa okulu daha çok severim." Ödülün Evde Pekiştirme Etkisi boyutu, evdeki akademik çalışmalarla ilgili ödül uygulamalarına karşı gelişmiş yüksek hassasiyet durumunu anlatmaktadır. Bu boyuttaki madde örnekleri şöyledir: "Dersimi çalıştıktan sonra annem ve babam tarafından ödüllendirildiğimde ders çalışma isteğim artar." ve "Annem ve babam beni ödüllendirmek için istediklerimi alacak olsalar daha çok ders çalışırım."

\subsubsection{Ortaöğretim Öğrencileri için Okul Tükenmişliği Ölçeği (ООTÖ)}

Ölçek, Aypay (2012) tarafından geliştirilmiş olup yapı geçerliği AFA ve DFA analizleri ile test edilmiştir. AFA'da KMO değeri 0.88; Bartlett's Testi sonucu, $\left(\chi^{2^{(946)}}=5517,651, p<.01\right)$, manidar bulunmuştur. Varimax Döndürme sonrası, öz değeri 1'den büyük ve toplam varyansın \% 61'ünü açıklayan yedi faktörlü bir yapı belirlenmiştir. Faktörlerin isimleri, özdeğerleri ve açıkladıkları varyanslar sırasıyla şöyledir: Okula illgi Kaybı (3.70; (\%10.89), Ders çalışmaktan Tükenme (3.65; \%10.75), Aileden Kaynaklı Tükenmişlik (3.22; \%9.48), Ödev Yapmaktan Tükenme (2.60; \%7.66), Öğretmen Tutumlarından Bunalma ve Sıkılma (2.58; \%7.60), Dinlenme ve Eğlenme Gereksinimi (2.52; \%7.41), Okulda Yetersizlik (2.33; \%6.86). Yedi faktörün maddelerle ilgili ortak varyansları .43.77 arasındadır. ООTÖ'nün faktörleri toplam puanla orta, birbirleriyle düşük ya da orta düzeyde bir korelasyona sahiptir. OOTÖ’nün AFA ile belirlenen yapısını doğrulamak için uygulanan DFA'da modelin uyum indeksleri $\left[\chi^{2^{(506)}}=1141.11, p<.01, \chi^{2} / s d=2.25, G F I=0.93, A G F I=0.91, P G F I=0.90\right.$, RMSEA $=0.05, C F I=0.94]$ modelin büyük oranda iyi uyum gösterdiğini ortaya koymuştur. ООTÖ faktörleri için Cronbach Alpha güvenirlik katsayıları sırasıyla şöyledir: .86, .82, .83, .67, .75, .72, 72 . Ölçekten alınan yüksek puanlar tükenmişliğini yüksek olduğu anlamına gelmektedir. Okula il|gi Kaybı boyutu, öğrencinin okula yönelik olumlu duygularının zayıflaması ve olumsuz duygular geliştirmesi durumunu anlatmaktadır. Bu boyuttaki bir madde örneği, "Okula gitmek istemiyorum." 
biçimindedir. Ders Çalışmaktan Tükenme boyutu, öğrencilerde ders çalışma faaliyetlerinin yol açtı̆̆ı yorgunluk, anlamsızlık ve bıkkınlık hislerini anlatmaktadır. Bu boyuttaki bir madde örneği, "Ders çalışmayı anlamsız buluyorum." biçimindedir. Aileden kaynaklı Tükenmişlik boyutu, ebeveynlerin okul dersleri konusunda çocuklarından aşırı beklenti ve baskılarından bunalma ve yorgun düşme halini anlatmaktadır. Bu boyuttaki bir madde örneği, "Ailemin sürekli daha fazla ders çalışmamı istemesinden yoruldum." biçimindedir. Ödev yapmaktan Tükenme boyutu, öğrencilerde okul ödevlerinin yol açtığı yorgunluk, anlamsızlık ve bıkkınlık hislerini anlatmaktadır. Bu boyuttaki bir madde örneği, "Ödev yapmaktan o kadar bıktım ki ödev yapmayı hep erteliyorum." biçimindedir. Öğretmen Tutularından Bunalma ve Sıkılma boyutu, öğretmenlerin öğrenciler üzerindeki baskıcı ve aşırı talep kâr tutumlarının öğrencilerde yol açtığı bunalma ve sıkıntı durumunu anlatmaktadır. Bu boyuttaki bir madde örneği, "Öğretmenlerimizin sürekli ders çalışın demesinden ve öğüt vermesinden bunaldım." biçimindedir. Dinlenme ve Eğlenme Gereksinimi boyutu, öğrencilerin okulla ilgili görev ve sorumlulukları dolayısıyla dinlenme ve eğlenme intiyaçlarını karşılayamama durumlarını anlatmaktadır. Bu boyuttaki bir madde örneği, "Ders çalışmaktan dinlenmeye ve eğlenmeye zaman bulamıyorum" biçimindedir. Okulda yetersizlik boyutu, okuldaki akademik çalışmalar konusunda öğrencilerde oluşan yetersizlik hislerini anlatmaktadır. Bu boyuttaki bir madde örneği, "Ne kadar ders çalışırsam çalışayım kendimi hep yetersiz hissediyorum." biçimindedir.

\subsection{Verilerin Analizi}

Verilerin öncelikle normallik varsayımını karşılayıp karşılamadığı çarpıklık katsayıları ve normal dağılım eğrilerine göre incelenmiş (Büyüköztürk, 2006) ve normal dağılım gösterdiği belirlenmiştir. Veriler betimsel analizler ve Çoklu Doğrusal Regresyon Analizi Tekniği ile analiz edilmiştir. Öğrencilerin akademik bağlama ilişkin ödül bağımlııklarının okul tükenmişliğinin alt faktörlerini yordayıp yordamadı̆̆ının belirlenmesi amacıyla Çoklu Doğrusal Regresyon Analizleri gerçekleştirilmiştir. Bu analizlerde ödül bağımlıl̆ğı ölçeğinin alt faktör (ödüle bağlı şartlı performans, ödülün okulda pekiştirme etkisi ve ödülün evde pekiştirme etkisi) puanları bağımsız değişkenler olarak; okul tükenmişliği ölçeğinin alt faktör (okula ilgi kaybı, ders çalışmaktan tükenme, aileden kaynaklı tükenmişlik, ödev yapmaktan tükenme, öğretmen tutumlarından bunalma ve sıkılma, dinlenme ve eğlenme gereksinimi, okulda yetersizlik) puanları da bağımlı değişkenler olarak analizlere dâhil edilmiştir.

\section{BULGULAR}

Akademik bağlamda ödül bağımlılı̆ının okul tükenmişliğinin alt boyut düzeylerini yordayıp yordamadığını belirlemek amacıyla Çoklu Doğrusal Regresyon Analizleri yapılmıştır. Okul tükenmişliği alt boyut puanlarının akademik bağlamda ödül bağımlılı̆̆ı değişkeni ile .10 ve üstündeki bir düzeyde açıklandığının belirlendiği analiz sonuçları tablolaştırılarak sunulmuştur. Ancak analiz sonuçlarına göre, .10'dan daha düşük açıklanma düzeylerine dair bulgulara tablolaştırmadan yer verilmiştir.

Okula ilgi kaybı tükenmişlik düzeyinin akademik bağlamda ödül bağımlılı̆ı ile yordanmasına ilişkin Çoklu Doğrusal Regresyon Analizi sonuçlarına göre, akademik bağlamda ödül bağımlılı̆ı okula ilgi kaybı tükenmişlik düzeyini anlamlı bir biçimde yordamamaktadır $\left(R=0.123, R^{2}=0.015, p<.01\right)$. Ders çalışmaktan tükenme tükenmişlik düzeyinin akademik bağlamda ödül bağımlılığı ile yordanmasına ilişkin Çoklu Doğrusal Regresyon Analizi sonuçlarına göre, akademik bağlamda ödül bağımlılığı ders çalışmaktan tükenme düzeyini anlamlı, ancak düşük düzeyde yordamaktadır $\left(R=0.251, R^{2}=0.063\right.$, $\mathrm{p}<.01)$. Ödül bağımlıı̆ının üç boyutu birlikte öğrencilerin aileden kaynaklı tükenmişlik puanlarındaki toplam varyansın \%6'sını açıklamaktadır. Regresyon katsayılarının anlamlılı̆ına ilişkin t-testi sonuçlarına göre, ödüle bağlı şartlı performans değişkeni ders çalışmaktan tükenme düzeyinin anlamlı bir yordayıcıdır.

Aileden kaynakıı tükenmişlik düzeyinin akademik bağlamda ödül bağımlılığı ile yordanmasına ilişkin Çoklu Doğrusal Regresyon analizi sonuçlarına göre, akademik bağlamda ödül bağımlılı̆ı aileden 
kaynaklı tükenmişlik düzeyini anlamlı, ancak düşük düzeyde yordamaktadır $\left(R=0.362, R^{2}=0.131\right.$, $\mathrm{p}<.01$ ). Bu analizin sonucu tablo 1'de verilmiştir.

Tablo 1. Aileden Kaynaklı Tükenmişlik Boyutunun Akademik Bağlamda Ödül Bağımlılığı ile Yordanmasına Illişkin Sonuçlar

\begin{tabular}{llllllll}
\hline Değişken & $\mathrm{B}$ & $\begin{array}{l}\text { Standart } \\
\mathrm{Hata}_{\beta}\end{array}$ & $\beta$ & $\mathrm{t}$ & $\mathrm{p}$ & $\begin{array}{l}\text { ikili } \\
\mathrm{r}\end{array}$ & $\begin{array}{l}\text { Kısmi } \\
\mathrm{r}\end{array}$ \\
\hline Sabit & 8.687 & .823 & & 10.553 & .000 & & \\
Ödüle Bağlı Şartlı Performans & .115 & .044 & .191 & 2.623 & .009 & .320 & .160 \\
Ödülün Okulda Pekiştirme Etkisi & .178 & .079 & .186 & 2.263 & .024 & .325 & .139 \\
Ödülün Evde Pekiştirme Etkisi & .050 & .090 & .041 & .560 & .576 & .240 & .035 \\
\hline
\end{tabular}

$\mathrm{R}=0.362 \quad \mathrm{R}^{2}=0.131 \quad \mathrm{~F}_{(3-340)}=13.148 \quad \mathrm{P}=.000$

Tablo 1'deki ikili ve kısmi korelasyonlara göre, ödüle bağlı şartlı performans ile aileden kaynaklı tükenmişlik arasında pozitif ve orta düzeyde $(r=0.32)$ bir ilişki vardır. Diğer iki değişken kontrol edildiğinde bu iki değişken arasındaki korelasyon $r=0.16$ 'dır. Ödülün okulda pekiştirme etkisi ile aileden kaynaklı tükenmişlik arasında pozitif ve orta düzeyde ( $r=0.33)$ bir ilişki vardır, diğer iki değişken kontrol edildiğinde ise korelasyon $r=0.14$ 'tür. Ödülün evde pekiştirme etkisi ile aileden kaynaklı tükenmişlik arasında pozitif ve düşük düzeyde ( $r=0.24)$ bir ilişki vardır, diğer iki değişken kontrol edildiğinde ise korelasyon $r=0.04$ 'tür.

Ödüle bağlı şartlı performans, ödülün okulda pekiştirme etkisi ve ödülün evde pekiştirme etkisi değişkenleri birlikte, öğrencilerin aileden kaynaklı tükenmişliklerindeki toplam varyansın \%13'ünü açıklamaktadır. Standardize edilmiş regresyon katsayısına $(\beta)$ göre, bu üç yordayıcı değişkenin aileden kaynakıı tükenmişlik üzerindeki göreli önem sırası; ödüle bağlı şartlı performans, ödülün okulda pekiştirme etkisi ve ödülün evde pekiştirme etkisi biçimindedir. Regresyon katsayılarının anlamlılı̆ıına ilişkin t-testi sonuçlarına göre, ödüle bağlı şartı performans ve ödülün okulda pekiştirme etkisi değişkenleri aileden kaynaklı tükenmişlik düzeyinin anlamlı birer yordayıcıdır.

Ödev yapmaktan tükenme düzeyinin akademik bağlamda ödül bağımlılığı ile yordanmasına ilişkin Çoklu Doğrusal Regresyon Analizi sonuçlarına göre, akademik bağlamda ödül bağımlılığı ödev yapmaktan tükenme tükenmişlik düzeyini anlamlı, ancak düşük düzeyde yordamaktadır $(R=0.298$, $\left.R^{2}=0.089, p<.01\right)$. Ödül bă̆ımlılığının üç boyutu birlikte öğrencilerin ödev yapmaktan tükenme puanlarındaki toplam varyansın \%9'unu açıklamaktadır. Regresyon katsayılarının anlamlılı̆ına ilişkin t-testi sonuçlarına göre, ödüle bağlı şartı performans değişkeni ödev yapmaktan tükenme düzeyinin anlamlı bir yordayıcısıdır.

Öğretmen tutumlarından bunalma ve sıkılma tükenmişlik düzeyinin akademik bağlamda ödül bağımlılığı ile yordanmasına ilişkin Çoklu Regresyon Analizi sonuçlarına göre, akademik bağlamda ödül bağımlılığı öğretmen tutumlarından bunalma ve sıkılma tükenmişlik düzeyini anlamlı, ancak düşük düzeyde yordamaktadır $\left(R=0.362, \quad R^{2}=0.131, p<.01\right)$. Bu analizin sonucu tablo 2 'de verilmiştir. Tablo 2'deki ikili ve kısmi korelasyonlara göre, ödüle bağlı şartlı performans ile öğretmen tutumlarından bunalma ve sıkılma arasında pozitif ve orta düzeyde $(r=0.32)$ bir ilişki vardır. Diğer iki değişken kontrol edildiğinde bu iki değişken arasındaki korelasyon $r=0.15^{\prime}$ tir. Ödülün okulda pekiştirme etkisi ile öğretmen tutumlarından bunalma ve sıkılma arasında pozitif ve orta düzeyde $(r=0.33)$ bir ilişki vardır, diğer iki değişken kontrol edildiğinde ise korelasyon $r=0.12$ 'dir. Ödülün evde pekiştirme etkisi ile öğretmen tutumlarından bunalma ve sıkılma arasında pozitif ve düşük düzeyde $(r=0.27)$ bir ilişki vardır, diğer iki değişken kontrol edildiğinde ise korelasyon $r=0.08$ 'dir. 
Tablo 2. Öğretmen Tutumlarından Bunalma ve Sıkılma Tükenmişlik Boyutunun Akademik Bağlamda Ödül Bağımlılığı ile Yordanmasına İlişkin Sonuçlar

\begin{tabular}{llllllll}
\hline Değişken & $\mathrm{B}$ & $\begin{array}{l}\text { Standart } \\
\mathrm{Hata}_{\beta}\end{array}$ & $\beta$ & $\mathrm{t}$ & $\mathrm{p}$ & $\begin{array}{l}\text { Ikili } \\
\mathrm{r}\end{array}$ & $\begin{array}{l}\text { Kısmi } \\
\mathrm{r}\end{array}$ \\
\hline Sabit & 6.625 & .704 & & 9.416 & .000 & & \\
Ödüle Bağlı Şartlı Performans & .092 & .037 & .178 & 2.449 & .015 & .316 & .150 \\
Ödülün Okulda Pekiştirme Etkisi & .134 & .067 & .163 & 1.991 & .048 & .325 & .122 \\
Ödülün Evde Pekiştirme Etkisi & .095 & .077 & .091 & 1.239 & .217 & .270 & .076 \\
\hline \multicolumn{1}{c}{$\mathrm{R}^{2}=0.134$}
\end{tabular}

$\mathrm{R}=0.366 \quad \mathrm{R}^{2}=0.134 \quad \mathrm{~F}_{(3-340)}=13.436 \quad \mathrm{P}=.000$

Ödüle bağlı şartlı performans, ödülün okulda pekiştirme etkisi ve ödülün evde pekiştirme etkisi değişkenleri birlikte, öğrencilerin öğretmen tutumlarından bunalma ve sıkılma puanları ile düşük düzeyde ve anlamlı bir ilişki vermektedir. $\left(R=0.366, R^{2}=0.134, p<.01\right)$. Bu üç değişken birlikte öğrencilerin öğretmen tutumlarından bunalma ve sıkılma puanlarındaki toplam varyansın \%13'ünü açıklamaktadır. Standardize edilmiş regresyon katsayısına ( $\beta$ ) göre, bu üç yordayıcı değişkenin öğretmen tutumlarından bunalma ve sıkılma üzerindeki göreli önem sırası; ödüle bağlı şartlı performans, ödülün okulda pekiştirme etkisi ve ödülün evde pekiştirme etkisi biçimindedir. Regresyon katsayılarının anlamlılığına ilişkin t-testi sonuçlarına göre, ödüle bağlı şartı performans ve ödülün okulda pekiştirme etkisi değişkenleri öğretmen tutumlarından bunalma ve sıkılma düzeyinin anlamlı birer yordayıcısıdır.

Dinlenme ve eğlenme gereksinimi tükenmişlik düzeyinin akademik bağlamda ödül bağımlılığı ile yordanmasına ilişkin Çoklu Doğrusal Regresyon Analizi sonuçlarına göre, akademik bağlamda ödül bağımlılı̆ı dinlenme ve eğlenme gereksinimi tükenmişlik düzeyini anlamlı, ancak düşük düzeyde yordamaktadır $\left(R=0.247, R^{2}=0.061, p<.01\right)$. Ödül bağımlılığının üç boyutu birlikte öğrencilerin dinlenme ve eğlenme gereksinimi puanlarındaki toplam varyansın \%6'sını açıklamaktadır. Regresyon katsayılarının anlamlılığına ilişkin t-testi sonuçlarına göre, ödüle bağ/ı şartı performans değişkeni dinlenme ve eğlenme gereksinimi düzeyinin anlamlı bir yordayıcısıdır.

Okulda yetersizlik tükenmişlik boyutunun akademik bağlamda ödül bağımlılığı ile yordanmasına ilişkin Çoklu Doğrusal Regresyon Analizi sonuçlarına göre, akademik bağlamda ödül bağımlılığ okulda yetersizlik tükenmişlik düzeyini anlamlı, ancak düşük düzeyde yordamaktadır $(R=0.232$, $\left.\mathrm{R}^{2}=0.054, \mathrm{p}<.01\right)$. Ödül bağımlılığının üç boyutu birlikte öğrencilerin okulda yetersizlik puanlarındaki toplam varyansın \%5'ini açıklamaktadır. Regresyon katsayılarının anlamlılığına ilişkin t-testi sonuçlarına göre, ödüle bağ/ı şartıı performans değişkeni okulda yetersizlik düzeyinin anlamlı bir yordayıcisıdır.

\section{SONUÇ, TARTIŞMA VE ÖNERILER}

Bu çalışmada akademik bağlamda ödül bağımlılığının lise öğrencilerinde okul tükenmişliğini yordayıcı bir değişken olup olmadığı belirlenmeye çalışılmıştır. Bu amaçla yapılan çoklu regresyon analizleri akademik bağlamda ödül bağımlıı̆ının okul tükenmişliğinin okula ilgi kaybı tükenmişlik boyutu hariç diğer tüm boyutlarını (ders çalışmaktan tükenme, aileden kaynakı tükenmişlik, ödev yapmaktan tükenme, öğretmen tutumlarından bunalma ve sıkılma, dinlenme ve eğlenme gereksinimi, okulda yetersizlik) düşük düzeylerde yordadığını göstermiştir.

Lise düzeyindeki öğrenciler için geliştirilen akademik bağlamda ödül bağımlılığının üç boyutlu bir yapısı olduğu belirlenmiştir. Bu boyutlar ödül beklentisine bağlı şartlı performans, ödülün okulda pekiştirme etkisi ve ödülün evde pekiştirme etkisi biçiminde adlandırılmaktadır. Bu boyutlardan evde ve okulda pekiştirme etkisi boyutları daha çok evde ve okuldaki akademik çalışmalarda ödüle karşı yüksek bir duyarlık hali içinde olunduğuna işaret ederken; ödül beklentisine bağlı şartlı performans boyutu geliş̧miş bağımlılık halini göstermektedir (Aypay, 2015). Akademik bağlamda ödül bağımlılığının okul tükenmişliğini yordamasına ilişkin çoklu regresyon analizleri, ödül bağımlılı̆ının ödül beklentisine bağlı şartlı performans boyutunun okul tükenmişliğinin altı 
boyutunda da tükenmişlik düzeylerini anlamlı bir biçimde yordadığını göstermiştir. Analizler aileden kaynaklı tükenmişlik ve öğretmen tutumlarından bunalma ve sıkılma tükenmişlik boyutlarında ödül beklentisine bağlı şartı performans boyutunun yanında ödülün okulda pekiştirme etkisi boyutunun da anlamlı bir yordayıcı olduğunu göstermiştir.

Akademik bağlamda ödül bağımlılığının aileden kaynaklı tükenmişlik ve öğretmen tutumlarından bunalma ve sıkılma tükenmişlik boyutlarındaki toplam varyansları diğer tükenmişlik boyutlarına göre daha büyük bir oranda açıklamasına ilişkin bulgular dikkat çekici ve anlamlıdır. Çünkü öğrencilerin akademik çalışmaları ile ilgili ödüllendirmeler evlerde anne ve babalar, okullarda da öğretmenler tarafından yapılmaktadır. Öyle görünüyor ki ödüle karşı yüksek düzeyde bir duyarlılık ya da bağımlılık geliştiren öğrenciler akademik çalışmaları konusunda muhatap oldukları kişilerin (ebeveynler ve öğretmenler) tutumlarından daha fazla tükenmektedirler. Bunun akla uygun bir açıklaması, ebeveynlerin ve öğretmenlerin öğrencilerden ders çalışmaları konusundaki aşırı talep kâr hallerinin ya da öğrencinin akademik performansı konusundaki yüksek beklentilerinin öğrencilerin ödül alma intiyaçlarını ya da beklentilerini yeterince doyurmuyor olabileceğidir.

Ebeveynler ve öğretmenler öğrencileri ödüllendirme uygulamalarında zamanlama, ödül tipi ve ödüllendirme biçimi ile ilgili seçimlerinde oldukça dikkatli olmak zorundadırlar. Çünkü doğru bir biçimde dikkatle yapılmayan ödüllendirme uygulamalarının istenmeyen sonuçlar doğurduğu araştırma bulgularının ortaya koyduğu önemli bir bilgidir (Bursztyn ve Jensen, 2014; Deci ve diğerleri, 1999; Levitt ve diğerleri, 2012). Ayrıca ödülün bağımlılık yapıcı bir özelliğe sahip olduğu (Delgado ve diğerleri, 2003; Knutson ve diğerleri, 2001; Pink, 2009), akademik bağlamda ödüle karşı oluşmuş bağımlılık halinin aynı zamanda bireyleri ceza hassasiyeti yüksek bireyler olmaya yatkın hale getirdiği de (Aypay, 2015) bilinmektedir.

Analizler akademik bağlamda ödül bağımlılığının lise öğrencilerinin okul tükenmişliklerini düşük düzeyde yordadığını göstermektedir. Ödüle bağımlı hale gelmek her ne kadar istenmeyen bir durum ise de ödül almanın kendisinin bireye yaşattığı kısa süreli bir doyum ya da haz vardır (Pink 2009). Ödül bağımlılığının okul tükenmişliğinin güçlü bir yordayıcısı olmamasının bu kısa süreli rahatlama ve doyum hisleriyle ilişkili olabileceği düşünülmektedir. Yani akademik çalışmalar nedeniyle ara sıra alınan ödüllerin ödül bağımlısı öğrencilerde oluşturduğu geçici haz duyguları belki de okul kaynaklı stresin etkisini kısmen azaltıyor olabilir.

Bu çalışmada araştırma örneklemindeki kız öğrencilerin erkek öğrencilerden sayıca daha fazla olması ve çalışmanın devlet liselerinde öğrenim gören öğrenciler üzerinde yapılmış olması bu araştırmanın sınırlııklarını oluşturmaktadır. Bununla birlikte çalışmanın bulgularının öğrenciler açısından ciddi olumsuz sonuçlar doğurma potansiyeli olan okul tükenmişliğinin düşük düzeyde de olsa yordayıcısı olan bir değişkeni literatüre tanıttığı için önemli olduğu düşünülmektedir. Öyle görünüyor ki öğrencilerde okul tükenmişlik sendromu gelişmesinin önüne geçebilmek için ebeveynlerin ve öğretmenlerin yapabilecekleri şeylerden biri de onları ödül bağımlısı haline getirecek dışsal ödüllere sıkça başvurma biçimindeki uygulamalardan kaçınmaları olacaktır. Bundan sonra yapılacak araştırmalarda, evde ve okulda ebeveynlerin ve öğretmenlerin öğrencileri akademik çalışmaya teşvik etmek amacıyla ne gibi ödüller kullandıkları, bu ödülleri ne sıklıkta verdikleri, ödüllendirmeye alternatif ne gibi teşvik yöntemlerine başvurdukları belirlenmeye çalışılabilir. Öğrencilerin okul tükenmişliğini önlemeye yönelik olarak hazırlanacak programların bir parçası olarak, ebeveynlere ve öğretmenlere öğrencilerin içsel motivasyonlarını geliştirmeye yönelik bilinç ve tutumlar kazandırılabilir. 


\section{Kaynakça}

Aypay, A. (2011). Ilköğretim II. Kademe Öğrencileri için Okul Tükenmişliği Ölçeği: Geçerlik ve Güvenirlik Çalışması. Kuram ve Uygulamada Eğitim Bilimleri- Educational Sciences: Theory \& Practice, 11(2), 511-527.

Aypay, A. (2012). Ortaöğretim Öğrencileri için Okul Tükenmişliği Ölçeği (OOTO). Kuram ve Uygulamada Eğitim Bilimleri-Educational Sciences: Theory \& Practice, 12(2), 782-787.

Aypay, A. (8-10 Haziran 2015). Ödül Bir Ceza Mı? Ödül Bağımılığından Ceza Hassasiyetine. 2. Uluslararası Avrasya Eğitim Araştırmaları Kongresi'nde Sunulan Bildiri, Hacettepe Üniversitesi, Ankara, Türkiye.

Aypay, A. (5-8 Mayıs 2016a). Akademik Bağlamda Ödül Bağımlıı̆̆ının Ebeveynlik Tarzı ve Cinsiyet ile ilişskileri. VIII. Uluslararası Eğitim Araştırmaları Kongresi'nde Sunulan Bildiri, Çanakkale Onsekiz Mart Üniversitesi, Çanakkale, Türkiye.

Aypay, A. (30 Mayıs - 2 Haziran 2016b). Lisede Ceza Hassasiyeti ve Ödül Bağımlılı̆̆ının Denetim Odağı, Okul Sevgisi, Akademik Güdülenme ile ilişkileri. XVIII Amce-Amce-Waer Kongresi'nde Sunulan Bildiri., Eskişehir Anadolu Üniversitesi, Eskişehir, Türkiye.

Bandura, A. (1976). Self-Reenforcement: Theoretical and Methodological Considerations. Behaviorism, 4(2), 135-155.

Bask, M. Ve Salmela-Aro, K. (2013). Burned Out to Drop Out: Exploring the Relationship Between School Burnout and School Dropout. European Journal of Psychology of Education, 28(2), 511528.

Bursztyn, L. \& Jensen, R. (2014). Should Schools Recognize Or Award Achievement? Mimeo, UCLA. Https://Liberalarts.Utexas.Edu/Files/Ms37643/Leaderboard_Bursztyn_Jensen.Pdf Adresinden 01/09/2016 Tarihinde Alınmıştır.

Cameron, J. Ve Pierce, W.D. (1994). Reinforcement, Reward, and Intrinsic Motivation: A MetaAnalysis. Review Of Educational Research, 64, 363-423.

Ching, G.S. (2012). Looking into the Issues of Rewards and Punishment in Students. International Journal of Research Studies in Psychology, 1(2), 29-38. Https://Link.Springer.Com/Journal/10212 adresinden 18/12/2014 tarihinde alınmıştır.

Covington, M.V. (2000). Goal Theory, Motivation, And School Achievement: An Integrative Review. Annual Review Of Psychology, (51), 171-200.

Deci, E.L., Koestner, R. ve Ryan, R.M. (1999). A Meta-Analytic Review of Experiments Examining The Effects of Extrinsic Rewards on Intrinsic Motivation. Psychological Bulletin, 125(6), 627-668.

Delgado, M.R., Locke, H.M., Stenger, V.A. ve Fiez, J.A. (2003). Dorsal Striatum Responses To Reward And Punishment: Effects Of Valence And Magnitude Manipulations. Cognitive, Afective, \& Behavioral Neuroscience, 3(1), 27-38.

Duru, E., Duru, B. ve Balkıs, M. (2014). Analysis of Relationships Among Burnout, Academic Achievement, and Self-Regulation. Educational Sciences: Theory \& Practice, 14(4), 1274-1284.

Dyrbye, L.N., Thomas, M.R., Harper, W., Massie, F.S., Jr, Power, D.V., Eacker, A., Et Al. (2009). The Learning Environment and Medical Student Burnout: A Multicentre Study. Medical Education, 43, 274-282.

Dyrbye, L.N., Thomas, M.R., Power, D.V., Durning, S., Moutier, C., Massie, F.S. Jr, Et Al., (2010). Burnout and Serious Thoughts of Dropping Out of Medical School: A Multi-Institutional Study. Academic Medicine, 85(1), 94-102.

Knutson, B., Adams, C.M., Fong, G.W. ve Hommer, D. (2001). Anticipation of Increasing Monetary Reward Selectively Recruits Nucleus Accumbens. Journal of Neuroscience, 21, RC159. Http://Www-Psych.Stanford.Edu/ Span/Publications/Bk01jn.Pdf Adresinden 01/01/2015 Tarihinde Alınmıştır. 
Levitt, S. D., List, J.A. , Neckermann, S. ve Sadoff, S. (2012). The Behavioralist Goes to School: Leveraging Behavioral Economics to Improve Educational Performance, NBER Working Paper

Http://Rady.Ucsd.Edu/Docs/Faculty/Levitt_Et_Al_Behavioralist_School_NBER_WP18165.Pdf Adresinden 02/09/2016 Tarihinde Alınmıștır.

Ormrod, J. E. (2011). Human Learning (6th Ed.). Upper Saddle River, NJ: Pearson.

Pintrich, P.R. (2000). Multiple Goals, Multiple Pathways: The Role of Goal Orientation in Learning and Achievement. Journal Of Educational Psychology, 92(3), 544-555.

Reynolds, G. S. (1975). A Primer of Operant Conditioning. Glenview, IL: Scott, Foresman.

Roeckelein, J. E. (1998). Dictionary of Theories, Laws, and Concepts in Psychology. Westport. CT: Greenwood Press.

Schaufeli, W. B., Martínez, I.M., Pinto, A.M., Salanova, M. \& Bakker, A.B. (2002). Burnout and Engagement in University Students A Cross-National Study. Journal of Cross-Cultural Psychology, 33(5), 464-481.

Skinner, B. F. (1971). Beyond Freedomanddignity. New York: Knopf.

Tolman, E.C. Ve Honzik, C.H. (1930). Introductionandremoval of Reward, Andmazeperformance in Rats. University Of California Publications in Psychology, 4, 257-275.

Tolman, E. C. (1938). The Determiners of Behavior at A Choicepoint. Psychological Review, 45,1-41. 


\section{Extended Summary}

As instructional activities are conducted in schools, rewarding continues to be used as a tool to yield the outcomes of these activities and make them effective. However, negative effects of rewarding on students are mentioned in a considerable number of studies in the literature. Some of the findings on the effects of rewarding showed that addiction to rewards develops in individuals who are aware that they would be rewarded after a task. The concept of reward addiction in the academic context has started to be examined in the literature only recently. Reward addiction is defined as the state in which students' feelings and behaviours in the academic context are controlled by rewards. It is hypothesised that reward addiction in the academic context causing dependence to the outside world in experiencing the feeling of pleasure and no-reward clues leading to stress as well as negative feelings and behaviours in students can be related to school burnout that is caused by long-term stress factors at school. Research findings revealed that school burnout syndrome negatively and significantly affect students' academic lives. In this regard, it is thought that reward addiction in the academic context can cause to school burnout in students. However, no studies in the literature have ever examined the relationship between reward addiction and school burnout. For this reason, this study aimed to determine whether high school students' reward addiction was a significant predictor of the school burnout syndrome they experienced. The participants were 265 students who were studying at $9^{\text {th }}, 10^{\text {th }}$ and $11^{\text {th }}$ grades at two state high schools in a Turkish city. Reward Addiction Scale for High School Students, and School Burnout Scale For High School Students were employed to gather the data. Multiple Linear Regression Analysis was conducted to analyse the data gathered. In the analysis, the participants' scores in the sub-factors of the reward addiction scale (reward-dependent conditioned performance, reinforcing effect of reward at school, and reinforcing effect of reward at home) were included as independent variables, while those in the sub-factors of the school burnout scale (losing interest in school, burnout from studying,burnout due to family, burnout from doing homework, being bored and tired of teacher attitudes, the need to rest and have fun, and incompetence at school) as dependent variables. According to the results of the analyses, reward addiction in the academic context significantly predicted the burnout level of losing interest in school $\left(R=0.123, R^{2}=0.015, p<.01\right)$. Reward addiction in the academic context significantly predicted the burnout from studying, but at a weak level $\left(R=0.251, R^{2}=0.063, p<.01\right)$. The results of the t-test regarding the significance of the regression coefficients showed that the variable rewarddependent conditioned performance was a significant predictor of the burnout from studying. Reward addiction in the academic context significantly predicted the burnout due to family, but at a weak level $\left(R=0.362, R^{2}=0.131, p<.01\right)$. According to the t-test results, the variables rewarddependent conditioned performance and reinforcing effect of reward at school were significant predictors of the burnout due to family. Reward addiction in the academic context significantly predicted the burnout from doing homework, but at a weak level $\left(R=0.298, R^{2}=0.089, p<.01\right)$. The results of the t-test regarding the significance of the regression coefficients showed that the variable reward-dependent conditioned performance was a significant predictor of the burnout from doing homework. Reward addiction in the academic context significantly predicted the burnout level of being bored and tired of teacher attitudes, but at a weak level $\left(R=0.362, R^{2}=0.131, p<.01\right)$. According to the t-test results, the variables reward-dependent conditioned performance and reinforcing effect of reward at school were significant predictors of being bored and tired of teacher attitudes. Reward addiction in the academic context significantly predicted the need to rest and have fun, but at a weak level $\left(R=0.247, R^{2}=0.061, p<.01\right)$. The t-test results revealed that the variable reward-dependent conditioned performance was a significant predictor of the need to rest and have fun. Reward addiction in the academic context significantly predicted the burnout level of 
incompetence at school, but at a weak level $\left(R=0.232, R^{2}=0.054, p<.01\right)$. The results of the t-test regarding the significance of the regression coefficients showed that the variable reward-dependent conditioned performance was a significant predictor of the level of incompetence at school. It is notable and meaningful that reward addiction in the academic context explained the variances in burnout due to family and being bored and tired of teacher attitudes to a higher extent compared to other burnout dimensions. This is because students are rewarded for their academic work by their parents at home, and by their teachers at school. It seems that the students who develop a high level of sensitivity, or addiction to rewards burn out more intensely due to the attitudes of individuals (i.e. parents and teachers) whom they deal with in their academic works. A reasonable explanation for this could be that parents' and teachers' excessive demands from students regarding their academic works, or high expectations of their academic performance may not sufficiently meet students' needs, or expectations of being rewarded.

The analyses revealed that reward addiction in the academic context predicted high school students' school burnout at a weak level. Although being addicted to rewards is not a desired situation, there is a short-term satisfaction or pleasure that individuals have after receiving a reward. The fact that reward addiction is not a strong predictor of school burnout can be related to this temporary relaxation and satisfaction. It is thought that the findings of this study are of significance since it introduces a variable that is a predictor, although at a weak level, of school burnout to the literature. 